\title{
PENGEMBANGAN MEDIA BELAJAR MENGAJAR IPA DENGAN PENERAPAN MELALUI PEMBELAJARAN KONSTRUKTIVISME DEVELOPMENT OF LEARNING MEDIA TO TEACH IPA BY APPLICATION THROUGH CONSTRUCTIVITY LEARNING
}

\author{
Grafika Ramadhanti Ekananda \\ Program Studi Pendidikan IPA, Fakultas Keguruan dan Ilmu Pendidikan, Universitas Jember \\ e-mail: grafikanandha16@gmail.com
}

\begin{abstract}
Media is a means that can be used to convey information to students, one of which is learning constructivism. In learning. Constructivism is one of the schools of philosophy of knowledge which emphasizes that our knowledge is our own (formed) construction. At present a teacher must stimulate students so that students become more active. The learning delivered by the teacher that is theoretical will get less than optimal results. Learning media becomes interesting when it can contribute positively to learning outcomes. because every subject that is usually considered difficult to understand becomes very interesting, the learning media also has an aesthetic appeal so that an attractive and eye-catching display will motivate users to be involved in the learning process. The results of the study showed that the application of learning media in the activities of explaining science lessons in class could optimize students' learning motivation.
\end{abstract}

Keywords: Media, constructivism, learning.

\section{PENDAHULUAN}

Pendidikan adalah proses interaksi guru dengan siswa, yang bertujuan meningkatkan perkembangan mental sehingga mandiri dan utuh. Hal ini membuat siswa mempunyai peran belajar serta guru sebagai fasilitator, motivator, dan sekaligus evaluator dalam kegiatan belajar mengajar. Peran guru sebagai fasilitator dalam kegiatan pembelajaran, antara lain menyediakan kemudahan kepada siswa dalam belajar. Peran guru sebagai motivator dalam kegiatan pembelajaran antara lain memberikan rangsangan bagi pengembangan inisiatif dan kreatifitas para siswa serta mendorong siswa untuk menerapkan ide/gagasan barunya. Peran guru yang lain adalah sebagai evaluator atau penilai, artinya guru harus mampu menilai kemajuan belajar siswa baik kenyataan yang terjadi di lapangan, guru cenderung dominan dalam mengajarkan konsep atau materi pelajaran di kelas sehingga siswa semakin tergantung pada inisiatif guru. Dalam hal ini semua kegiatan di kelas berpusat pada guru, apabila keadaan ini berlangsung secara terus menerus, maka upaya untuk meningkatkan kualitas pembelajaran tidak akan mengalami perubahan. Pembelajaran yang dilaksanakan miskin aktivitas sehingga siswa merasa bosan dan pada akhirnya kemampuan berpikir tidak berkembang, hal tersebut mengakibatkan pembelajaran menjadi tidak bermakna. Dari hal tersebut akan secara otomatis mengurangi ketertarikan siswa terhadap pelajaran IPA. Untuk menumbuhkan minat dan ketertarikan belajar IPA, guru harus berani menggunakan model-model pembelajaran inovatif. Salah satu model pembelajaran yang berpusat pada siswa yaitu model pembelajaran kontruktivisme (Najemi,Chairin. dkk. 2014:1).

Pendidikan adalah usaha sadar dan terencana untuk mewujudkan suasana belajar dan proses pembelajaran agar peserta didik secara aktif mengembangkan potensi dirinya untuk memiliki kekuatan spiritual keagamaan, pengendalian diri, kepribadian, kecerdasan, akhlak mulia, serta keterampilan yang diperlukan dirinya, masyarakat, bangsa dan negara (Depdiknas, UU No. 20 Tahun 2003, Bab 1, Pasal 1). Berdasarkan hal tersebut bahwa sebuah pendidikan yang benar yaitu suatu proses yang direncanakan untuk membentuk siswa yang tidak hanya cakap dalam pengetahuan

\section{ScienceEdu Vol. II. No. 2 Desember 2019}

Received 14 October 2019| Received in revised form 11 November 2019| Accepted 25 November 2019| Published

online 2 December 2019 
dalam ilmu tertentu tetapi memiliki sikap dan keterampilan yang berguna bagi mereka dalam menjalani kehidupannya (Agustini, Fitria. dkk. 2017: 35).

Proses pendidikan yang diharapkan dijabarkan pada Badan Standar Nasional Pendidikan, Peraturan Pemerintah Nomor 19 Tahun 2005 tentang Standar Nasional Pendidikan, Pasal 19 ayat (1) tentang standar proses, dinyatakan bahwa: Proses pembelajaran pada satuan Pendidikan diselenggarakan secara interaktif, inspiratif, menyenangkan, menantang, memotivasi peserta didik untuk berpartisipasi aktif serta memberikan ruang yang cukup bagi prakarsa, kreativitas dan kemandirian sesuai dengan bakat, minat, dan perkembangan fisik serta psikologis peserta didik. Hal tersebut di atas diperjelas lagi dalam Badan Standar Nasional Pendidikan, Permendiknas No. 22 Tahun 2006 tentang standar isi dinyatakan bahwa pembelajaran IPA sebaiknya dilaksanakan secara inkuiri ilmiah (scientific inquiry) untuk menumbuhkan kemampuan berpikir, bekerja dan bersikap ilmiah serta mengkomunikasikannya sebagai aspek penting kecakapan hidup(Agustini, Fitria. dkk. 2017: 35-36).

Von Glaserfeld dan Matthews yang dikutip dalam Paul Suparno (1997:18), menyatakan bahwa konstruktivisme adalah salah satu aliran filsafat pengetahuan yang menekankan bahwa pengetahuan kita adalah konstruksi (bentukan) kita sendiri. Pada pendekatan konstruktivisme, pengetahuan adalah bukan suatu fakta yang tinggal ditemukan, melainkan suatu perumusan yang diciptakan orang yang sedang mempelajarinya. Para konstruktivis percaya bahwa pengetahuan itu ada dalam diri seseorang yang sedang mengetahui. Pengetahuan tidak dapat dipindahkan begitu saja dari otak seseorang (guru) ke kepala orang lain (siswa). Langkah-langkah model pembelajaran konstruktivisme menurut Tyler dalam Sumatowa (2006:55), dibagi dalam 3 fase sebagai berikut, 1) Fase Eksplorasi yaitu guru memancing pengetahuan awal siswa mengenai materi yang akan dipelajari pada saat itu, 2) Fase Klarifikasi, Pada fase ini informasi berupa pengetahuan awal siswa di perdalam agar bisa menambah pengetahuan siswa mengenai materi yang dipelajari, dan 3) Fase Aplikasi, Pada fase ini guru mengevaluasi kegiatan pembelajaran yang telah dipelajari agar bisa mengetahui apakah perencanaan sesuai dengan pelaksanaan. Belajar merupakan proses konstruksi pengetahuan melalui keterlibatan fisik dan mental siswa secara aktif, juga merupakan proses yang menghubungkan bahan yang dipelajari dengan pengalamanpengalaman yang dimiliki seseorang sehingga pengetahuannya mengenai objek tertentu menjadi lebih kokoh. Siswa mampu mengkonstruksikan pengetahuan untuk dirinya sendiri, dan bukan pengetahuan yang datang dari guru "diserap" oleh siswa. Ini berarti bahwa setiap siswa akan mempelajari sesuatu yang sedikit berbeda dengan pelajaran yang diberikan (Muijs dan Reynolds, 2011:97). Menurut Syaiful Bahri D dan Aswan Zain (1996:95), model pembelajaran konstruktivisme memiliki kelebihan antara lain sebagai berikut.

1) Dapat membina siswa dengan kebiasaan menerapkan pengetahuan, sikap dan keterampilan secara terpadu

2) Dapat mengembangkan kemandirian siswa diluar pengawasan guru

3) Dapat merangsang dan mengembangkan kreatifitas siswa dalam bentuk ide, gagasan dan terobosan dalam memecahkan suatu masalah

4) Memberikan kesempatan kepada siswa untuk mengemukakan pendapatnya dengan bahasa sendiri.

Kekurangan model pembelajaran konstruktivisme sebagai berikut.

1) Memerlukan waktu yang cukup lama

2) Tidak mudah merangsang siswa dengan memberikan pertanyaan yang sesuai dengan tingkat berpikirnya siswa

3) Tidak semua siswa ikut berperan aktif dalam proses pembelajaran melalui percobaan

4) Jumlah alat yang disediakan harus disesuaikan dengan jumlah siswa, jika hal tersebut tidak dipenuhi maka akan menimbulkan hasil yang kurang memuaskan. (Najemi, Chairin. dkk. 2014: 1-4). 
Pembelajaran konstruktivisme merupakan pendekatan pembelajaran yang menekankan pada proses pembelajaran, dimana dalam proses pembelajaran siswa dituntut untuk aktif dalam membangun sendiri pengetahuannya sehingga siswa mampu berpikir mandiri. Pada pembelajaran ini guru tidak mentransfer pengetahuan yang telah dimilikinya, akan tetapi guru berperan sebagai fasilitator untuk membantu agar proses pengkonstruksian pengetahuan oleh siswa dapat berjalan lancar. Dalam kegiatan pembelajaran, model pembelajaran konstruktivisme dapat membangkitkan minat karena siswa dituntut aktif dalam membangun sendiri pengetahuannya yang kemudian siswa mampu berpikir mandiri, maka penerapan model pembelajaran konstruktivisme dilakukan sebagai salah satu upaya untuk meningkatkan minat siswa terhadap materi yang dipelajari melalui interaksinya terhadap alam melalui pengalaman langsung, sehingga prestasi belajar siswa dapat meningkat. Pembelajaran IPA melalui pendekatan konstruktivisme diharapkan siswa dapat terlihat aktif dalam pelajaran sehingga siswa dapat membuat hubungan antara pengetahuan yang dimilikinya dengan pengetahuan ilmiah yang baru ditemukan. Dari latar belakang di atas, maka perumusan masalah penelitian ini adalah: bagaimana upaya meningkatkan minat siswa dalam pembelajaran IPA melalui model pembelajaran konstrukstivisme dan bagaimana upaya meningkatkan prestasi belajar siswa dalam pembelajaran IPA melalui model pembelajaran konstruktivisme. Aplikasi model pembelajaran konstruktivisme dalam materi mata pelajaran IPA diharapkan dapat meningkatkan minat dan prestasi belajar IPA Najemi,Chairin.dkk.2014:4).

Berdasarkan Suyomo, Suharto \& Sujoko (1998), "Sains/Ilmu Pengetahuan Alam (IPA) adalah ilmu pengetahuan yang dibentuk melalui proses berpikir sistematis, empiris yang didasari dengan sikap keingintahuan (curiousity), keteguhan hati (courage), ketekunan (persistence) yang dilakukan oleh individu untuk menyingkap rahasia alam semesta". Proses berpikir sistematis sains atau lebih dikenal dengan proses sains meliputi mengamati, mengklasifikasi, menginfer (menarik kesimpulan), memprediksi, mencari hubungan, mengukur, mengkomunikasikan, merumuskan hipotesis, melakukan eksperimen, mengontrol variabel, menginterpretasikan data, dan menyimpulkan. Berdasarkan hal tersebut, diketahui bahwa IPA sebagai suatu kumpulan pengetahuan yang tersusun secara sitematis dapat memunculkan proses berpikir ilmiah(Wulandari ,Ria.2017:30).

Media merupakan alat-alat grafis, photografis atau elektronis untuk menangkap, memproses dan menyusun kembali informasi visual atau verbal. Media pendidikan memiliki pengertian nonfisik yang dikenal sebagai software (perangkat lunak), yaitu kandungan pesan yang terdapat dalam perangkat keras yang merupakan isi yang ingin disampaikan kepada siswa. Teknologi pendidikan adalah kajian dan praktik etis untuk menfasilitasi belajar dan memperbaiki kinerja dengan menciptakan, menggunakan dan mengelola proses dan sumber-sumber teknologi yang sesuai(Wulandari ,Nais.dkk.2017:710).

\section{METODE PENELITIAN}

Metode yang digunakan dalam penelitian ini adalah media pembelajaran dengan menggunakan pembelajaran konstruktivisme. Penelitian ini dilakukan untuk mengetahui apakah para siswa dapat membuat media sendiri tanpa bantuan guru.

\section{HASIL DAN PEMBAHASAN}

Teori belajar yang digunakan adalah teori belajar konstruktivisme. Teori belajar konstruktivistik menyatakan bahwa siswa harus dapat membangun pengetahuannya sendiri. Pengetahuan merupakan konstruksi kognitif seseorang terhadap objek, pengalaman maupun lingkungannya.

Seorang guru dalam proses pembelajaran selalu memberikan materi secara teoritis dengan menggunakan metode ceramah, metode diskusi, metode tanya jawab dan metode-metode lainnya. Faktanya, proses 
pembelajaran yang berlangsung seperti iniakan mendapatkan hasil yang tidak memuaskan. Oleh karena itu, seorang guru dapat memanfaatkan teknolgi untuk merangsang daya tangkap serta pemahaman siswa terhadap materi pelajaran IPA.

IPA berasal dari kata sains yang berarti alam. Sains merupakan pengetahuan hasil kegiatan manusia yang besifat aktif dan dinamis tiada henti-hentinya serta diperoleh melalui metode tertentu yaitu teratur, sistematis, berobjek, bermetode dan berlaku secara universal (Suyoso, 1998). Abdullah (1998) menyatakan bahwa "IPA merupakan pengetahuan teoritis yang diperoleh atau disusun dengan cara yang khas atau khusus, yaitu dengan melakukan observasi, eksperimentasi, penyimpulan, penyusunan teori, eksperimentasi, observasi dan demikian seterusnya kait - mengkait antara cara yang satu dengan cara yang lain". IPA merupakan suatu rangkaian konsep yang berkaitan satu sama lain dengan bagan-bagan konsep yang telah berkembang sebagai suatu hasil eksperimen dan observasi, yang bermanfaat untuk eksperimentasi dan observasi lebih lanjut (Depdiknas, 2006). Berdasarkan hal tersebut, maka dapat dikatakan bahwa IPA merupakan pengetahuan yang bebrasal dari hasil kegiatan manusia dengan melalui langkah-langkah ilmiah, yaitu observasi, eksperimentasi, penyimpulan, penyusunan teori, dan seterusya dilakukan secara teratur, sistematis, berobjek, bermetode dan berlaku secara universal.

Pembelajaran IPA merupakan kegiatan yang dilakukan untuk mempelajari Ilmu Pengetahuan Alam yang berhubungan dengan objek alam serta persoalannya dengan ruang lingkup makhluk hidup, energi dan perubahannya, bumi dan alam semesta serta proses materi dan sifatnya. Pembelajaran IPA dalam kajiannya terdiri dari tiga aspek yaitu Fisika, Biologi dan Kimia. Pada aspek Fisika, IPA lebih memfokuskan pada fenomena yang terjadi pad kehidupan sehari - hari, khususnya terkait benda-benda tak hidup. Pada aspek Biologi, IPA mengkaji pada persoalan yang terkait dengan makhluk hidup serta lingkungannya. Sedangkan pada aspek
Kimia, IPA mempelajari gejala-gejala kimia baik yang ada pada makhluk hidup maupun benda tak hidup yang ada di alam. Di sekolah, proses pembelajaran IPA dilakukan dengan cara berpikir dan bertindak yang responsif terhadap permasalahan baik lokal maupun global di lingkungan. IPA sebagai proses menyangkut prosedur atau cara kerja untuk memperoleh hasil (produk), proses ini dikenal sebagai proses ilmiah. Melalui proses ilmiah akan didapatkan temuan ilmiah. Pada proses ilmiah, secara tidak langsung terjadi berpikir ilmiah.

Proses pembelajaran pada penelitian tindakan kelas ini dalam 2 tahap. Tahap pertama terdiri dari 3 pertemuan dan Tahap kedua terdiri dari 3 pertemuan dengan menerapkan pembelajaran konstruktivisme.

\section{Tahap I}

Pada Tahap I dilaksanakan dalam 3 pertemuan, membahas tentang materi IPA dengan bahan fisika,biologi dan kimia dalam kehidupan sehari-hari. Langkahlangkah dalam pembelajaran ini sebagai berikut. Pada fase eksplorasi pembelajaran diawali dengan kegiatan merangsang dan memancing pengetahuan siswa untuk mengungkapkan idenya mengenai materi yang akan dibahas serta membuat media pembelajaran. Tugas guru dalam proses ini lebih menekankan untuk merangsang pemikiran siswa, memberikan persoalan, dan membiarkan siswa mengungkapkan gagasan dan konsepnya, serta kritis menguji konsep yang dibentuk siswa. Untuk memancing pemikiran dan ide siswa maka guru memberikan beberapa tugas dan tema yang berbeda pada tiap kelompok mengenai materi yang akan dibahas. Ketika guru melakukan pembagian tema yang akan di bahas setiap kelompok harus memiliki pemikiran tentang judul apa dan bahan materi apa yang akan di buat dalam media pembelajaran. Setelah itu untuk memudahkan siswa membentuk ide dan konsep kemudian guru mengenalkan berbagai macam contoh baik berupa benda maupun gambar. Yang terpenting dalam tahap ini adalah menghargai dan menerima pemikiran siswa apa pun adanya. Dengan tetap mengarahkan apakah pemikiran atau 
ide tersebut jalan atau tidak.Dalam fase klarifikasi guru lebih memperdalam lagi informasi berupa pengetahuan awal siswa dengan kegiatan diskusi. Sebelum diskusi dimulai guru membentuk beberapa kelompok siswa yang masing-masing kelompok beranggotakan 4-5 siswa. Pada awalnya siswa banyak yang kurang setuju dengan pembagian kelompok tersebut. Guru kemudian membujuk siswa kembali ke kelompok semula. Guru membimbing kelompok dalam melakukan

kegiatan diskusi. Pada waktu berdiskusi guru berkeliling membimbing siswa jika mengalami kesulitan, selain itu guru juga bertugas mengarahkan siswa jika terjadi kesalahan konsep. Setelah selesai mengerjakan media pembelajaran dengan kelompok, kemudian guru memberikan kesempatan untuk mempresentasikan hasil media yang sudah dibuat di depan kelas. Dari sinilah minat siswa mulai terlihat jelas dari pertemuan sebelumnya. Setelah semua anggota kelompok presentasi kemudian guru bersama-sama dengan siswa menyimpulkan hasil presentasi yang telah dibahas. Guru juga memberikan penguatan terhadap media serta materi yang dianggap penting supaya tidak terjadi kesalahpahaman konsep. Dalam fase aplikasi guru mengevaluasi kegiatan pembelajaran yang telah dilaksanakan. Kegiatan evaluasi ini dilakukan untuk mengetahui apakah perencanaan pembelajaran sesuai dengan yang dilaksanakan. Guru mengevaluasi kegiatan pembelajaran dengan memberikan tes. Pada Tahap I, guru secara umum sudah melaksanakan proses pembelajaran sesuai rencana pelaksanaan pembelajaran yang telah disusun akan tetapi keaktifan siswa pada saat proses pembelajaran berlangsung masih belum sepenuhnya tampak. Berdasarkan hasil observasi dan evaluasi pelaksanaan tindakan Tahap I dapat disimpulkan bahwa pembelajaran IPA dengan menggunakan model pembelajaran konstruktivisme sudah sesuai dengan prosedur yang direncanakan.

\section{Tahap II}

Berdasarkan refleksi yang dilakukan terhadap Tahap I, masih terdapat beberapa permasalahan yang harus diselesaikan sehingga pada Tahap II dapat diperbaiki. Hal-hal yang masih perlu dilakukan dalam memperbaiki kelemahan dan kekurangan pada tahap I untuk diperbaiki pada tahap II, dilaksanakan dengan cara sebagai berikut.

1) Guru memberikan motivasi secara intensif kepada siswa agar berperan aktif dalam proses pembelajaran.

2) Guru lebih intensif dalam melakukan pendampingan dalam kelompok supaya bisa bekerjasama secara optimal.

3) Guru memberikan waktu yang cukup untuk persiapan terlebih dahulu kepada kelompok yang akan presentasi.

4) Dalam pelaksanaan pembelajaran guru lebih bersikap tegas dan efisien terhadap waktu agar pembelajaran lebih efektif.

5) Guru mengingatkan dan memberikan teguran kepada siswa agar memperhatikan ketika penyampaian materi.

6) Guru lebih memberikan kesempatan kepada siswa untuk bertanya. Pada awal tahap II, guru membuka pertemuan dengan mengucap salam. Sebelum pembelajaran dimulai guru mengumumkan hasil evaluasi dan memberikan penghargaan kepada kelompok atas keberhasilannya. Siswa terlihat senang dan termotivasi untuk lebih meningkatkan nilainya pada evaluasi selanjutnya. Materi yang dibahas pada siklus ini yaitu gerak pada tumbuhan.

\section{KESIMPULAN}

Teori belajar konstruktivistik menyatakan bahwa siswa harus dapat membangun pengetahuannya sendiri. Pengetahuan merupakan konstruksi kognitif seseorang terhadap objek, pengalaman maupun lingkungannya.

Pembelajaran IPA merupakan kegiatan yang dilakukan untuk mempelajari Ilmu Pengetahuan Alam yang berhubungan dengan objek alam serta persoalannya dengan ruang lingkup makhluk hidup, energi dan perubahannya, bumi dan alam semesta serta proses materi dan sifatnya. Pembelajaran IPA dalam kajiannya terdiri dari tiga aspek yaitu Fisika, Biologi dan 
Kimia. Pada aspek Fisika, IPA lebih memfokuskan pada fenomena yang terjadi pad kehidupan sehari - hari, khususnya terkait benda-benda tak hidup. Pada aspek Biologi, IPA mengkaji pada persoalan yang terkait dengan makhluk hidup serta lingkungannya. Sedangkan pada aspek Kimia, IPA mempelajari gejala-gejala kimia baik yang ada pada makhluk hidup maupun benda tak hidup yang ada di alam.

Proses pembelajaran pada penelitian tindakan kelas ini dalam 2 tahap. Tahap pertama terdiri dari 3 pertemuan dan Tahap kedua terdiri dari 3 pertemuan dengan menerapkan pembelajaran konstruktivisme.

\section{SARAN}

Artikel ini masih jauh dari kata sempurna, mohon dijadikan maklum dan semoga dapat menjadi acuan dalam pembelajaran di sekolahan. Saya ucapkan banyak terima kasih.

\section{DAFATAR PUSTAKA}

Agustini, Fitria. dkk. 2017. Peningkatan Kemampuan Bertanya dan Penguasaan Konsep IPA melalui Pendekatan Question Formulation Technique (QFT). JURNAL PENELITIAN PENDIDIKAN. Vol 17 No 1:35-44.

Najemi, Chairin. dkk. 2014. Upaya Peningkatan Minat dan Prestasi Belajar IPA Siswa Kelas VIII SMP Negeri 12 Yogyakarta Tahun Pelajaran 2012/2013 melalui Model Pembelajaran Konstruktivisme. Jurnal Pendidikan IPA NATURAL Volume 1 No. 1:1-9.

Wulandari, Nais. dkk. 2017. Studi Literatur Pembelajaran Kimia Berbasis Masalah ditinjau dari Kemampuan Menggunakan Laboratorium Virtual. Seminar Nasional Teknologi Informasi, Komunikasi dan Industri (SNTIKI) 9 Fakultas Sains dan Teknologi, UIN Sultan Syarif Kasim Riau Pekanbaru: 709-715.

Wulandari, Ria. 2017. Berpikir Ilmiah Siswa dalam Pembelajaran IPA untuk Meningkatkan Literasi Sains.
Science Education Journal.Vol. 1 No. 1: 29-35. 